\title{
Persuasion, Justice and Democracy in Plato's Crito
}

YOSEF Z. LIEBERSOHN / Bar-Ilan University /

\section{Introduction}

Having provided the Laws' speech, Socrates ends the dialogue by turning to Crito and saying:

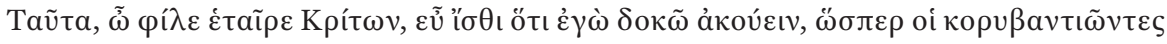

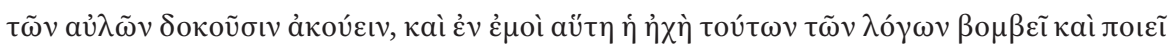

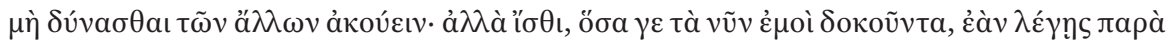

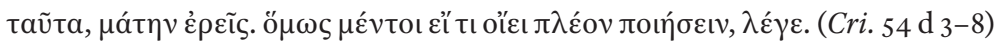

Be well assured, my dear friend, Crito, that this is what I seem to hear, as frenzied dervishes of Cybele seem to hear the flutes, and this sound of these words re-echoes within me and prevents my hearing any other words. And be assured that, so far as I now believe, if you argue against these words you will speak in vain. Nevertheless, if you think you can accomplish anything, speak. 
It is not clear from what Socrates says whether he wishes Crito to answer the arguments raised by the Laws or not. If he is really interested in hearing Crito's response to the Laws' speech, why mention the Corybants? If he does not want to hear Crito's answer he should not have ended with encouraging Crito to speak. Socrates seems strangely indecisive. ${ }^{1}$

In this paper I wish to argue that this closing paragraph of the $\mathrm{Crito}^{2}$ (to which I shall return in the last section of this paper) reflects and actually summarizes one of the main messages of Socrates to Crito in the Crito, ${ }^{3}$ namely that he should refrain from rhetorical speeches. Yet this criticism by Socrates of the Crito is also an attack of Plato against democracy. ${ }^{4}$ Socrates attempts to stop Crito using speeches and persuasion and thereby reduce the danger of democracy, since speeches, persuasion, and rhetoric are the basic mechanism of democracy. These are, however, the elements giving democracy its very legitimacy.

Socrates' final words are not the only puzzling feature in the Crito. Here are a few more, all of which will be treated in my analysis.

a. Although Crito makes several attempts to persuade Socrates to escape jail, Socrates never tries to persuade Crito that he ought to stay. Socrates wishes only for Crito to stop trying to persuade him.

b. The verb peithomai has two different meanings: 'to be persuaded' and 'to obey'. The verb appears frequently in a conversation dealing with free and forced persuasion. Is there a play on the verb in both its senses?

\footnotetext{
${ }^{1}$ Stokes (2005: 187-188) tries to explain what he takes to be "contradictory requirements". Basing his explanation on the dramatic situation, Stokes sees here a compromise Socrates makes between the need for a quick practical decision and "the convenances of the Platonic confutation or elenchus, including its generaly provisional nature" which "must be observed". He later writes (2005: 193): "Plato and his Socrates must provide the discussion in the Crito with both finality and provisionality. The occasion is exceptional”. But see Garver's remark (2014: 4): "The Laws have produced an argument that silences all others. This idea of a clinching or conclusive argument seems at odds with Socrates' own idea that he is always persuaded by the strongest argument”.

${ }^{2}$ This paragraph is usually discussed concerning the question whether the Laws' speech really gives the reader Socrates' (Plato's character in the Crito) own opinion or not. On this debate see Kraut (1984: 4), Weiss (1998: 134-145) and Harte (2005). See also Stokes (2005: 188-194) who criticizes Harte and Weiss' interpretation.

${ }^{3}$ These sentences may be regarded as nothing special, something like "As far as I, Socrates, am concerned nothing could be found to be said agaist the Laws' arguments, but if you still think you have something to say, speak.".Yet this is exactly what characterizes Plato's writing. Many 'innocent' passages also have an underlying meaning and the two meanings coexist. Indeed, it is Socrates' interlocutor (and correspondingly Plato's reader) who must decide which meaning to embrace.

${ }^{4}$ Determining the subject of any of Plato's dialogues is a difficult task. Even in cases where the subtitle points

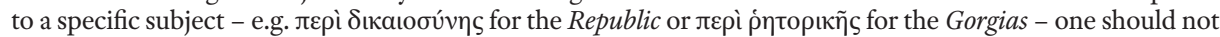
take it simply as a proof. Plato's Crito is no exception. The exact subject of the Crito has never been agreed upon. Already Adam (1888: v-vi) argues that the Crito, as against the Euthyphro and the Apologia “is Socrates' Apologia pro morte sua" (see also n. 12 below). Danzig (2010) argues that the Crito is Plato's own attempt to explain his behavior during Socrates' trial and its consequences. Other scholars have regarded the Crito as Plato and Socrates' attempt to explain why Socrates did not escape from jail. Moreover, despite Plato's account in the Crito, we have no other testimony independent of Plato's account for the story told in the Crito. Perhaps Plato invented the whole story, and his readers were aware of its fictional status. If so, his contemporaries would not have read the Crito as an explanation for an act which never happened.
} 
c. The term 'justice' and its cognates appear frequently in the Crito. We might have expected the "What is X?" question so typical of early Platonic dialogues ${ }^{5}$ to appear in this dialogue, but the nature of justice is never questioned.

\section{A preliminary note - Socrates, Crito, Plato and the reader}

In order to decipher Plato's intent in each dialogue one has to concentrate only on the characters of the dialogue, and as we all know Plato does not appear as an actor in any of his dialogues. With regard to the Crito it is only through the conversation between Socrates and Crito that Plato's view may be discerned concerning the issue discussed in the dialogue, whatever that may be. While Socrates may change his strategies in reaction to Crito's behaviour, it is Plato who orchestrates everything. Asking why Plato has caused the characters to act as they do is the key to unlocking Plato's own view.

One of the main issues clearly implicit in the conversation between Socrates and Crito, as I shall be arguing, is democracy, ${ }^{6}$ represented by Crito who plays the role of a typical Athenian citizen (despite his wealth). ${ }^{7}$ More particularly, the main issue concerns the dangers of democracy. Socrates first concentrates on the Many, and Crito's dependence on their view (Cri. 44 c 6 ff., immediately after Crito's speech at 44 b 6-c 5). Within this discussion lies an additional discussion (following Crito's second speech at 44 e 1-46 a 9) concerning justice and the question of the expert who should be obeyed (Cri. 46 b $1 \mathrm{ff}$.). ${ }^{8}$ I shall be arguing that from 48 a 10 to the end of the conversation Socrates turns to his last issue emphasizing speech, persuasion, and rhetoric, ${ }^{9}$ with everything said by Socrates from 48 a 10 onwards being preparatory work for the Laws' speech.

${ }^{5}$ E.g. Plat. Euthphr. 5 c 9-d 7; Lach.190 e 3. On this issue see also Moore (2011: 1032).

${ }^{6}$ Plato's critique of political and democratic rhetoric spans important parts of his corpus: the Republic, Gorgias, and the Menexenus, among others. My aim in this paper is not only to show that it appears in the Crito as well, but to point at the special way in which democracy is criticized, namely that rhetoric is a 'gentler' form of violence in that it enables one to break the law while remaining a law-abider in his consciousness. Hence I shall not go into Plato's larger critique against democracy and shall limit my discussion to what Plato has to say in the Crito alone.

7 The analysis presented here regards each Platonic dialogue as self-standing, with regard to its characters. Plato the dramatist shapes his characters according to his specific aims in each dialogue. Thus Gorgias of Plato's Gorgias should not be taken as a simple representation of the historical Gorgias, and the same applies to Crito. Historically Crito was, indeed, a wealthy aristocrat, but Plato can present him according to his specific aim in composing the Crito. On the other hand my description of Crito as "a typical Athenian citizen" should not be interpreted by treating Crito as a member of the democratic mob. Crito is shown in this dialogue to be indeed a wealthy man. He is a typical Athenian citizen in the sense that he gets along with democracy, and as I shall argue, he uses democratic stratagems in order to achieve his self-interested aims.

${ }^{8}$ The discussions are interconnected. The discussion of justice is added to the discussion concerning the opinion of the Many, and the 'discussion' (see note 10 below) concerning rhetoric is added to the previous two. Thus every discussion incorporates the previous one.

9 This last issue - rhetoric and persuasion - does not stand as an independent issue, but rather incorporates all previous issues and reveals their infrastructure. 
Having analyzed all of Socrates' moves we should then ask ourselves why Plato the playwright chose to arrange Socrates' moves in the way they appear. Why does a 'discussion'10 which focuses on speeches, persuasion, and rhetoric appear at the last stage? Because this last stage reveals the structure of the previous stages, I shall argue that Plato himself regards rhetoric as responsible for many of the problems and fallacies of democracy. ${ }^{11}$

In what follows I shall arrange my discussion into three main parts: 1 . speeches within democracy enable a citizen to break the law for self interest while still considering himself a law-abiding citizen; 2. speeches are in fact nothing but a fig-leaf for violent behaviour; 3. how and why the treatment of rhetoric appears only after discussions of the Many and Justice.

\section{Speeches as an infrastructure: Breaking the law while remaining a law- abiding citizen.}

Socrates was born into a democratic regime. He lived and acted in this regime, and eventually was sentenced and executed by democratic institutions. All this should be considered relevant in any analysis of the dialogue. Yet not a few scholars seem to take the Crito as dealing in the abstract with themes such as the state and the citizen, obeying or disobeying an unjust verdict, the nature of justice and the like. ${ }^{12}$

The main problem with Crito in this dialogue is not his obvious willingness to break the law for his own interests. ${ }^{13}$ It is the fact that by breaking the law he does not consider himself a law-breaker. Had Crito been a simple criminal, Socrates would not have brought the Laws' speech. ${ }^{14}$ This speech is intended for one who in principle accepts the laws' authority. Moreover, Crito considers himself to be not only a law-abiding citizen, but even a moral and just man. A discussion such as the one appearing at 49 a $4-c 9$ could have had an effect only on one who considers himself moral and just.

${ }^{10}$ The word 'discussion' has been put in commas because it is not a discussion in the regular sense of the word. The fictional speech purportedly made by the Laws is a form of discussion concerning rhetoric and persuasion presented in this way by Socrates.

${ }^{11}$ In a way it is not democracy which uses rhetoric but rather rhetoric and the use of doxa (instead of epistēmēe) which strengthens Democracy.

${ }^{12}$ See for example Adam (1888: v): "because in both \{sc. the Crito and the Phaedo $\}$ we are introduced to problems of more universal interest, in the Crito to the relation between the individual and the state", and (1888: xi): "but what really stands arraigned before him is the principle that alone renders possible the existence of any kind of state, aristocracy, no less than democracy, the nomos”. cf., e.g., Kraut (1984), Woozely (1979), Harte (2005).

${ }^{13}$ Crito's willingness to break the law is exemplified immediately at the beginning of the dialogue. Crito has succeeded in entering the jail earlier than law permits by bribing the guard, and is contemplating smuggling Socrates out of jail.

${ }^{14}$ Formally this speech is directed to Socrates, but Crito is the one who is to advise Socrates. Thus by dramatic manipulation the speech is for Crito. 
Thus, Crito considers himelf to be a law-abiding citizen and a moral man, but in fact is a citizen who breaks laws, and is an immoral person. These two traits are one and the same. Crito represents in this dialogue what Plato thought of the typical democratic citizen, and the dramatist locates the problem in the legitimizing power of speeches, persuasion and rhetoric.

In order to prove my claim I wish to focus on a strange phenomenon which I have elsewhere called 'the measure for measure argument'. ${ }^{15}$ In evaluating Crito's attitude toward the laws and justice three points should be emphasized. Firstly, Crito is presented throughout the dialogue as one who breaks the law. Secondly, Crito is fully aware that he is breaking the law. Thirdly, his breaking the law does not seem to bother him at all.

Already at the very beginning of the dialogue Crito has no qualms about bribing the guard in order to get into jail earlier. ${ }^{16} \mathrm{He}$ is even proud of it and of his connections with the guard. Throughout the whole of Crito's speech at 44 e 1-46 a 9 there is no hint whatsoever that Socrates would be doing anything wrong or unjust by escaping, although Crito is aware that Socrates would be breaking the law. ${ }^{17}$ Yet Crito regards himself as a law-abiding citizen. ${ }^{18}$ Socrates understands him as regarding himself as such, or he would not have adduced the Laws, whose speech would have an effect only on one who agrees that they should be obeyed. Crito's behavior may begin to be explained by comparing the Laws' speech with Crito's speech at 44 e 1-46 a 9.

The Laws' speech begins either where the Laws start speaking (Cri. 50 a 8), or at the formal beginning of the speech ( $\mathrm{Cri}$. $50 \mathrm{c} 5$ ). The second alternative is preferable. ${ }^{19}$ Between the first appearance of the Laws (Cri. 50 a 8-b 5) and the formal speech (Cri. 50 c 5-54 d 2) Socrates asks Crito a question which should be regarded as the key

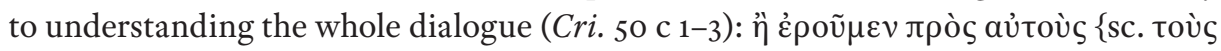

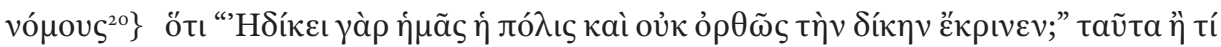

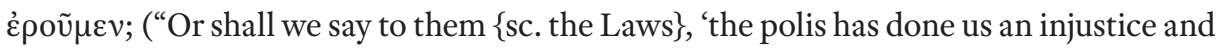
has not judged the case justly.' - shall we say that, or what?”).

Compare this question with Crito's speech (Cri. 44 e 1-46 a 9), in which he tries to persuade Socrates to escape from jail. Crito is aware that Socrates will not accept the suggestion to escape easily. ${ }^{21}$ Crito offers many and various reasons for Socrates to

\footnotetext{
${ }^{15}$ For an analysis of the phenomenon, see my paper (Liebersohn 2011: 51-53).

16 This view is shared by Congleton (1974: 432-446) and Weiss (1998: 52). For a different view see Stokes (2005: 24-25).

${ }^{17}$ Crito argues that the opposite would be true: if Socrates does not escape he would be doing the wrong thing (Cri. 45 c 6-7). On the terminology for 'unjust' and 'wrong' as opposed to 'illegal', see my paper (Liebersohn 2015). cf. also n. 29 below.

${ }^{18}$ Crito nowhere appears as saying something against the laws as such.

19 The reason is given immediately below.

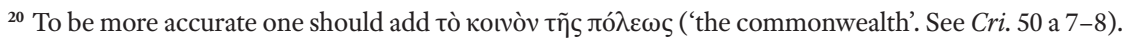

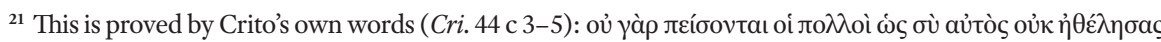

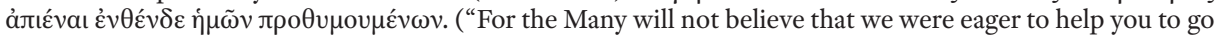


run away. Among them we find Crito reminding Socrates of his children; the fact that

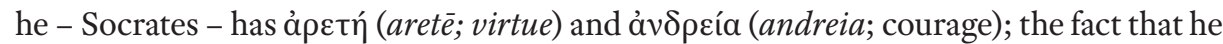
will be welcomed in every other polis, and the like. What is interesting is what does not appear here but should have appeared at the top of the list were it true: Socrates is simply not guilty, since the polis did him an injustice, and in such a case Socrates has the right to run away, i.e. to retaliate with injustice for an injustice done to him. The base of this argument, which I call 'the measure for measure argument', is the ancient moral code

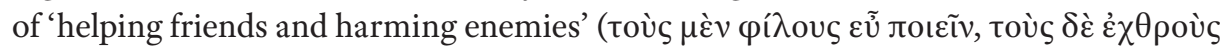
$\kappa \alpha \kappa \tilde{\omega} \varsigma) .{ }^{22}$ Crito uses many arguments, but not the most obvious one, the 'measure for measure argument'. Why not?

Compare this with Crito's response when, later, Socrates does suggest using the

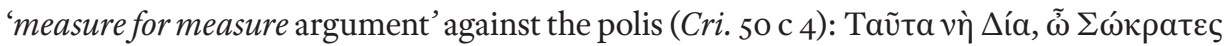
("That is what we shall say, by Zeus, Socrates"). The enthusiasm with which Crito embraces this argument ${ }^{23}$ when presented by Socrates contrasts with the total absence of this argument in Crito's original attempt to persuade Socrates to run away. Moreover, the fact that Socrates is the one who later raises this argument means that Crito would not have raised it on his own initiative. It may be inferred from all the above that the 'measure for measure argument' is Crito's latent justification for his behavior, allowing him to break the law while continuing to consider himself a loyal citizen of a democratic city, but is too natural and obvious to be considered worth mentioning.

The 'measure for measure argument' is always at the service of one whose opinion has been found by a court of law to be in the minority. Being in the minority may be rationalized as losing out to the superior rhetoric of the other side, ${ }^{24}$ rather than to any superior legal position. It is the rhetoric of the opposing side that the offended citizen reacts to rather than the validity of the laws. Crito sees Socrates as on the receiving end of superior rhetoric; Crito therefore feels justified in needing to save his own reputation and his friend's life even by breaking the law, but does not thereby invalidate the laws. ${ }^{25}$

Rhetorical speeches are evaluated not by criteria of truth but by what seems to be reasonable; thus the minority position is never proved false, and may continue to be

away from here, but you refused"). Yet up to this point Socrates has not said anything which could have given Crito the slightest impression that he will refuse to escape. From a dramatic point of view this means that the scene is set by the dramatist (Plato) in such a manner that we can assume that Crito comes to jail already aware of Socrates' reluctance. This sentence also allows both Socrates to find out Crito's attitude towards him, and the reader Crito's motives and way of thinking.

${ }^{22}$ See e.g., Plat. Men. 71 e 4; R. 332 d 7, 335 a 7, 362 c 1; Xen. Hier. VI 12, 2; D.H. Antiquitates Romanae

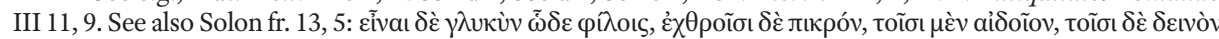
i $\delta \varepsilon \tilde{\varepsilon} v$ ("With these may I be sweet to my friends, bitter to my enemies, an object of reverence to the former, to the latter a dreadful vision to see").

${ }^{23}$ In a philosophical drama, not only what is said but also how it is said is important.

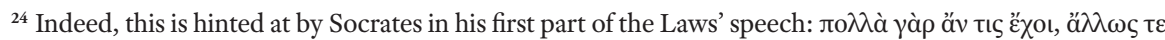

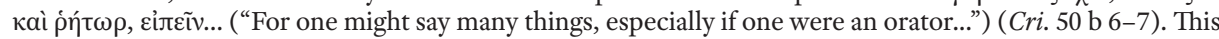
point has been emphasized by Weiss (1998: 84-95), and see my discussion on p. 154 and n. 35 below.

${ }^{25}$ For Socrates' response to this 'measure for measure' excuse see pp. 157-158, 163 below. 
regarded as valid by those who hold the minority position. Combine this with the old maxim of helping friends and harming enemies, which, according to Dover (1994: 273), never really disappeared even during the reign of democracy, ${ }^{26}$ and it is easy to see how rhetoric allows every citizen in a democratic regime to break the law now and then ${ }^{27}$ for self interests while regarding himself as a law-abiding citizen.

\section{Speeches in Practice: The worthlessness of using speeches}

Justice with its cognates appears frequently in the Crito; but its first appearance is at 44 e 1-46 a 9, and Crito is the first to use it. In two places within this speech we find the adjective dikaios and dikaioi: at 45 a 1 and at $45 \mathrm{c} 6$ :

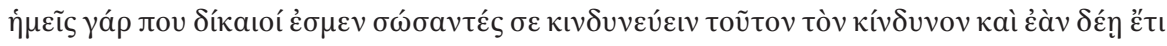
toútou $\mu \varepsilon i ́ \zeta \omega(C r i .45$ a 1-3)

since it is right for us to run this risk, and if necessary an even greater risk than this, provided we save you. ${ }^{28}$

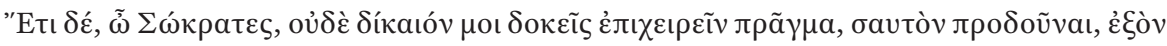

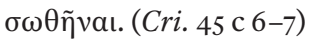

And besides, Socrates, what you are trying to do, seems to me, not to be the right thing betraying yourself when you might save yourself.

Taken by itself Crito's use of the adjective $\delta$ ík $\operatorname{sı}^{29}{ }^{29}$ pertains to using all the power one

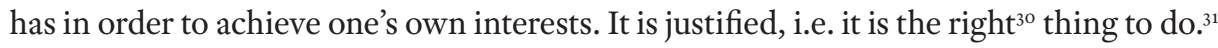
Thus, if Crito has the money and connections to get Socrates out of jail he is justified in

26 The same view is shared by Allen (2000). The author argues that although attempts done by democratic regime to transfer exerting punishments from the individual to the state, the moral code of 'helping friends and harming enemies' stayed firm and functioned well.

${ }^{27}$ The 'measure for measure argument' does not pertain to a specific act of law-breaking, but provides its advocate a sweeping justification to break the law whenever necessary while still being able to feel entirely loyal to the polis.

${ }^{28}$ Literally “we are right to run...”; cf. Adam (1888: 33): “'it is right that we' - The Greek idiom is personal while ours is impersonal".

${ }^{29}$ Dikaios as against to dikaion. In another paper (Liebersohn 2015) I have shown that the adjective itself is used in our dialogue to denote "what is in one's right to do", and the adjective with an article refers to a formal law. See also n. 17 above.

${ }^{30}$ Adam (1888: 36), referring to our text (Cri. 45 c 6) writes: "It is not correct to translate díkaıv here as 'just': it is 'right', 'moral'”.

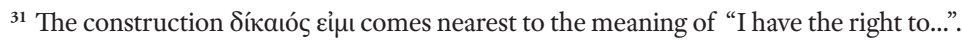


doing so. ${ }^{32}$ Indeed Crito uses many tools. He is more than willing to bribe the guard to enter the jail earlier, and he would probably do other things as well (see also Cri. 45 a 2-3). Yet a persuasive speech is a no less legitimate tool. ${ }^{33}$ Moreover, speech seems to be the most efficient tool for Crito to use especially with Socrates who refuses to escape. Crito's dominant - if not the only - motivation is his reputation among the Many; ${ }^{34}$ Socrates' refusal to escape is an impediment which Crito has to remove, and in order to persuade Socrates, the tool to use is speech.

The worthlessness of speeches is first hinted at in an innocent remark made by Socrates just before the Laws' speech and fully observed by examining the content of that speech. At 50 b 5-c 1, immediately before the beginning of the Laws' speech, Socrates

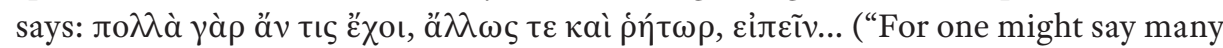
things, especially if one were an orator...”).

While Weiss (1988: 86-87) sees here mere irony I wish to argue that Socrates is serious. ${ }^{35} \mathrm{He}$ wants Crito to realize that were speeches to depend on rhetorical skill alone nothing would be safe. The Laws do exactly this with a rhetorical speech to counter Crito's.

Crito's speech at 44 e $1-46$ a 9 is intended to persuade Socrates to escape jail; ${ }^{36}$ the Laws' speech at 50 a $8-$ b 5 and 50 c 5-54 d 2 is intended to persuade Socrates not to escape but to remain in jail. Scholars have already demonstrated that the Laws' speech is a response to Crito's speech..$^{37}$ A couple of examples will suffice. Crito's argument based on Socrates' children becoming orphans (Cri. $45 \mathrm{c} \mathrm{10-d} \mathrm{4)}$ is turned on its head by the

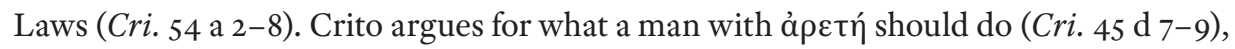
and this too is countered by the Laws (Cri. 54 a 1-2). The point Socrates seems to be

32 The same goes for Socrates; if he has the power to help himself (he has friends such as Crito) he also has the right to help himself, and not using this power would not be the right thing to do.

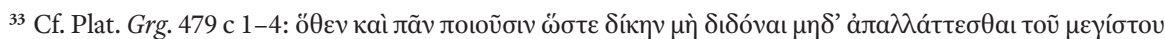

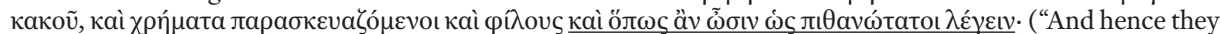
do all that they can to avoid punishment and to avoid being released from the greatet of evils; they provide themselves with money and friends, and cultivate to the utmost their powers of persuasion") (emphasis mine).

${ }^{34}$ Crito enumerates in his first speech at 44 b 6-c 5 two reasons - his friendship with Socrates and his reputation among the Many - but Socrates finds out, easily enough, which really motivates him. In his response at $44 \mathrm{~d} 1-5$ he does not mention friendship at all, and Crito does not protest.

${ }^{35}$ Weiss correctly observes, "by linking what the Laws say with what an orator would say, Socrates decisively dissociates himself from the speech of the Laws"; yet her later interpretation for the link as "Plato's way of warning the reader not to be too easily taken in by what they say." (1998: 87) seems to be going too far. Socrates is speaking to Crito; Plato does not speak directly to the reader. See also Moore (2011: 1038-1039) and his criticism of Weiss' view in n. 10. See also n. 24 above.

${ }^{36}$ There is another speech at $44 \mathrm{~b} 6-\mathrm{c} 6$, but this speech seems to be an emotional outburst, which need not concern us here.

${ }^{37}$ See Harte (2005) as against Kraut (1984). See also Allen who recognizes the relation between these two speeches but emphasizes the formal element: Crito's speech is "at random (...) a cluster of considerations that might have been offered in any order" (1972: 560) while the Laws' speech is a "unified and organic whole with head, trunk, and limbs, organized around a single self-consistent principle" (1972: 562); as for content, "The speech also meets, point by point, the prudential considerations that Crito urged in favor of escape" (1972: 562). 
making is that any rhetorical argument can be met by an equal and opposite argument, rendering all rhetorical arguments worthless in the process of reaching a correct decision..$^{8}$ The very last words of the Laws draw attention to the persuasive, non-factual,

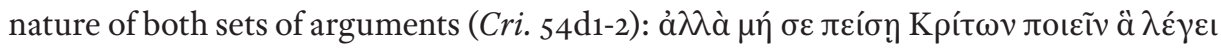

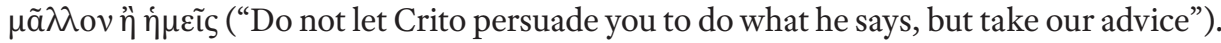

Socrates expresses the need for a criterion of truth immediately after Crito's second

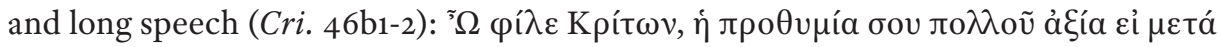

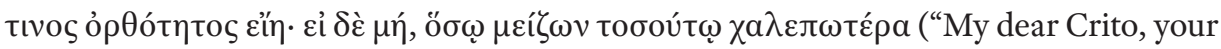
eagerness is worth a great deal, if it were with some rightness; but otherwise, the greater it is, the more hard to bear").

Rightness would seem to be connected not only with content (Crito's arguments should aim at the truth), but with form and method as well. ${ }^{39}$ Socrates demonstrates this by not waiting for Crito to give yet another speech, but immediately beginning a conversation in the form of questions and answers. ${ }^{40}$

The worthlessness of rhetorical speeches is one thing, but Socrates also regards speeches as an application of violence and compulsion..$^{41}$ Fifth-fourth century Greek thought tended to the view that logos ('speech', but also 'reason') could never be regarded as a violent compulsion, ${ }^{42}$ especially the rationally established laws set up to counter violent compulsion. Law in a democratic regime leads to a free and happy society. Law is contrasted with violence, e.g., in Xenophon's Memorabilia (Mem. I, 2, 9):

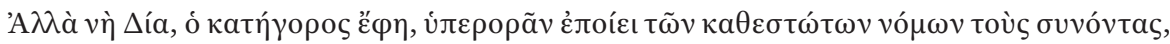

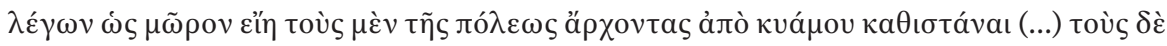

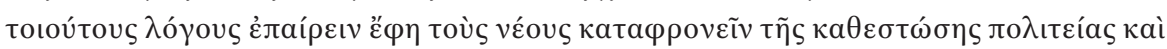

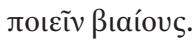

But, said the accuser, he taught his companions to despise the established laws by insisting on the folly of appointing public officials by lot (...) Such sayings, he argued, led the young to despise the established constitution and made them violent.

Xenophon contrasts violent compulsion with persuasion just a little later (Mem. I, 2, 10):

${ }^{38}$ Pace Allen (1972: 560) who considers the Laws' speech as a "philosophical rhetoric aimed at persuasion based on truth...”.

39 These two layers are interconnected.

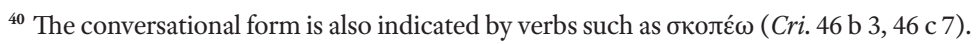

${ }^{41}$ Moreover, rhetoric may be the most dangerous form of exerting one's power since the persuasion in speech is usually covert.

${ }^{42}$ Gorgias' Encomium for Helen might be regarded as an exception, but the treatise is intended to praise rhetoric and persuasion. 


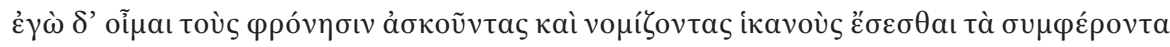

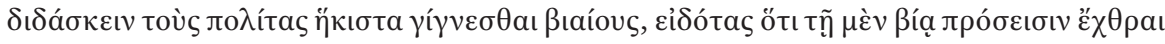

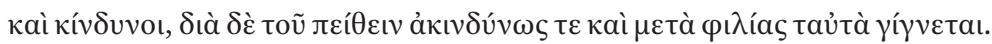

But I hold that they who cultivate wisdom and think they will be able to guide the people in prudent policy never lapse into violence: they know that enmities and dangers are inseparable from violence, but persuasion produces the same results safely and amicably.

The typical Athenian citizen prefers persuasion to force. Thus Socrates' accuser in I 2 , 9 is wrong to claim that Socrates' criticism of democracy (because positions are appointed by lot) necessarily leads to violence and a constitution based on force. ${ }^{43}$ Socrates as a wise man but also as a typical Athenian citizen would not have preferred violence over persuasion, since he would have understood the dangers involved.

Alcibiades in a sophistic argument with Pericles (Mem. I, 2, 39-46) contrasts compulsion with persuasion to make his point that the wealthy in democratic Athens are controlled not by law, but by violent compulsion:

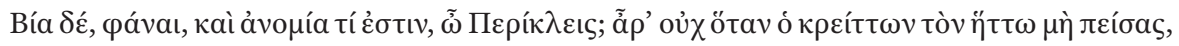

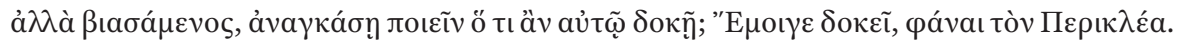

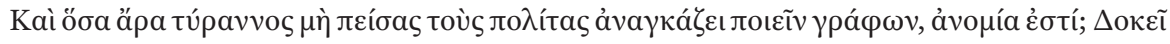

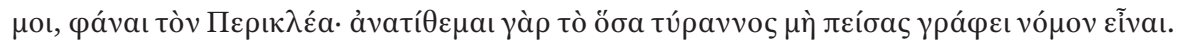

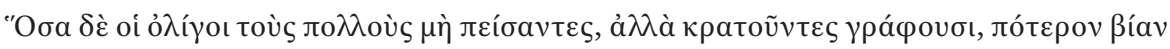

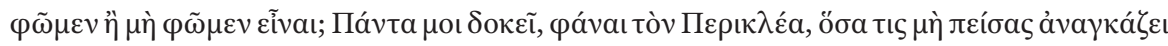

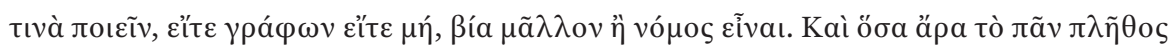

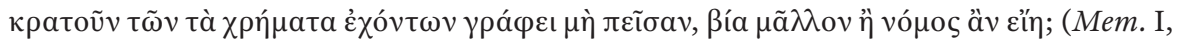
$2,44-45)$

"But force, the negation of law, what is that, Pericles? Is it not the action of the stronger when he constrains the weaker to do whatever he chooses, not by persuasion, but by force?"

"That is my opinion."

"Then whatever a despot by enactment constrains the citizens to do without persuasion, is the negation of law?"

"I think so: and I withdraw my answer that whatever a despot enacts without persuasion is a law."

${ }^{43}$ Which I take to refer to tyranny. See context further on. Thus the accuser considers democracy a defence against a regime which is based on bia. 
"And when the minority passes enactments, not by persuading the majority, but through using its power, are we to call that force or not?"

“Everything, I think, that men constrain others to do 'without persuasion,' whether by enactment or not, is not law, but force."

"It follows then, that whatever the assembled majority, through using its power over the owners of property, enacts without persuasion is not law, but force?"

The superior may cause the inferior to do what he wishes either through persuasion or through violent compulsion. Even if a tyrant writes down what he compels his subjects to do, the written rules are not considered laws, because law entails persuasion. Thus the wealthy Athenians do what they are told to by violent compulsion and not by law, despite the rules being written down, because they are not persuaded. It would follow that one persuaded to do what is prescribed would be acting freely. Thus the common perception would be that persuasion is what turns any enactment into a law, and that a law-abiding society is therefore free. ${ }^{44}$ It is this perception, I argue, that Socrates is trying to undermine in the Crito.

Throughout the dialogue, and especially in the Laws' speech, Socrates wishes Crito to understand that speeches are nothing but covert compulsion under the guise of a concept of justice, helping friends, and harming enemies in order to achieve one's own selfish interests. For Socrates, verbal persuasion and violent compulsion are one and the same..$^{45}$

The Laws in their speech agree that Socrates has been treated unjustly, but claim that he has no right to retaliate 'measure for measure' because he (like all other citizens) was brought up as a slave of the Laws:

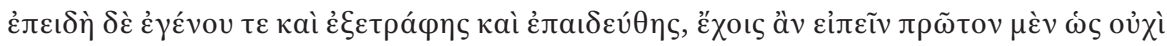

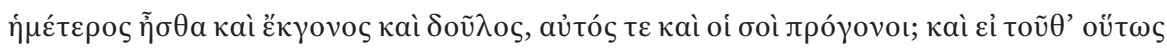

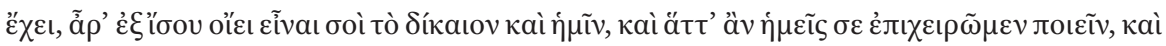

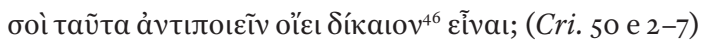

${ }^{44}$ Cf. Hdt. VIII 111, where Themistocles is said to have two gods, Persuasion and Necessity/Compulsion

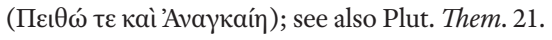

${ }^{45}$ Gorgias himself seems to understand this, agreeing that verbal persuasion enslaves, but he justifies his use of verbal persuasion by claiming that the enslavement of the one persuaded is voluntary and not through violent

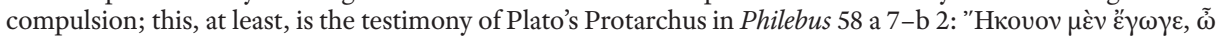

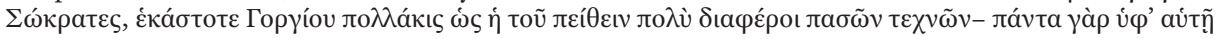

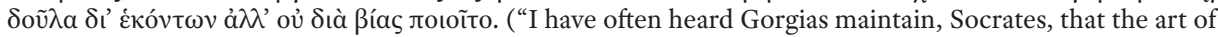
persuasion far surpassed every other; this, as he says, is by far the best of them all, for to it all things submit, not by compulsion, but of their own free will").

${ }^{46}$ This usage of 'right' (dikaion) at 50 e 7 is reminiscent of Crito's use of dikaios at 45 c 6. 
Well then, when you were born and nurtured and educated, could you say to begin with that you were not our offspring and our slave, you yourself and your ancestors? And if this is so, do you think right as between you and us rests on a basis of equality, so that whatever we undertake to do to you it is right for you to retaliate?

It is my contention that this explicitly counters Crito's implicit treatment of them. We have seen in section 3 how Crito assumes 'the measure for measure argument' to justify adopting the old moral code of helping friends and harming enemies in order to serve his own interests. Socrates throws this back in Crito's face by having the Laws say, in effect: "You, Crito, treat us as slaves; we treat you as a slave. ${ }^{47}$ You are willing to go so far as to harm us in order to achieve your aims; we are willing to harm you. You attempt to compel through verbal persuasion; so do we."

\section{Persuade or Be Persuaded = Obey}

In his attempt to make Crito aware of the violent character of rhetorical speech, Socrates makes good use of the verb $\pi \varepsilon i \theta \omega$ which means 'persuade' in its active form and 'be persuaded', or 'obey', in the passive form. ${ }^{48}$ It appears frequently in the Laws' speech: the only alternative to staying in jail that the Laws leave Socrates is to persuade them of his innocence: "and either persuade [the polis] or do whatever [the polis] commands" (Cri. 51 b 4); "you must do whatever the polis commands, in war and in court and everywhere, or persuade the polis where justice really is ${ }^{49}$ (Cri. $51 \mathrm{~b} \mathrm{10}-51 \mathrm{c} 1$ ); "and because after agreeing to obey us he neither obeys us nor persuades us that we are wrong, though we give him the opportunity and do not roughly order him to do what we command, but when we allow him a choice of two things, either to persuade us or to do our bidding, he does neither of these things" ${ }_{50}$ (Cri. 51 e 8-52 a 3).

Crito listening to the Laws' offer would find it reasonable since it seems anti-violent and democratic. A speech leading to a conviction, however, and any counter-speech leading to a possible acquittal would both be aiming at something other than a correct decision. Were Socrates to succeed in persuading the Laws of their mistake, the rhetorical

${ }^{47}$ Cf. Plat. Cri. 52 c 8-d 2 where the Laws again compare Socrates to a slave, this time because of his base attempt to escape and thereby flout the law.

${ }^{48}$ This point has already been emphasized by Garver (2012: 6 and nn. 12-13), though for a different aim and in a different context.

${ }^{49}$ The words "where justice really is" are ambiguous, referring either to the location of justice in a particular case, or to the very notion of justice.

${ }^{50}$ One can go back to Socrates' question leading to the Laws' speech at 49 e 9-50 a 1 and detect already there

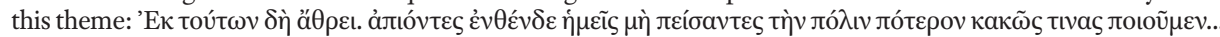
("Now observe what follows. If we go away from here without persuading the city to let us go, do we treat some

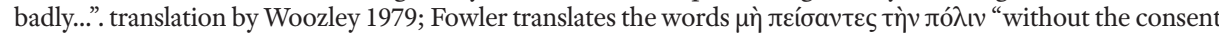
of the state" which misses the whole point). 
means employed would be no guarantee that justice had been done. The Laws emphasize this problem with rhetoric when they appear to believe that Socrates should remain in jail even if the verdict were unjust, so long as the verdict was accepted formally in a court of law (Cri. 51 a 3-4). In other words, the Laws do not mind the legal execution of an innocent person. The Laws' seemingly innocent suggestion, unremarkable in the Athenian democracy, that Socrates persuade them of their mistake or do what he is told, actually turns out to be nothing but violent compulsion, with no connection to justice, a point made explicitly so that even a typical Athenian such as Crito might take the hint. Crito had ended his long speech by commanding Socrates to obey him (and break the law by escaping - Cri. 46a8-9). It is in reaction to this that Socrates raises the need for rightness (see Cri. 46b1-2). Throughout the dialogue Socrates hints at the violent nature of the sort of persuasion aimed at by rhetoric; by mentioning rightness he also indicates the non-violent nature of dialectic persuasion. It is in this context that the ambiguity between 'be persuaded' and 'obey' (the same passive forms of the verb $\pi \varepsilon i \theta \omega$ ) becomes significant. Plato exploits the ambiguity for his own purposes..$^{51}$

The verb $\pi \varepsilon i ́ \theta \omega$ appears, especially in the passive form, fifteen times in the Crito..$^{52}$ Plato clearly exploits the two meanings of the verb for the purposes of this dialogue..$^{53}$ Crito uses the passive form in the sense of 'obey' (Cri. 45 a 3 and 46 a 8), ${ }^{54}$ attempting to compel Socrates to accept his offer delivered by means of a rhetorically persuasive speech. Socrates reacts to the kind of citizen Crito represents by giving this speech, and to the compulsion lurking in this democratic device of persuasion. Nowhere does Socrates (unlike the Laws) require obedience, and he is explicitly opposed to it in the following passage (Cri. $48 \mathrm{~d}$ 9-e 5):

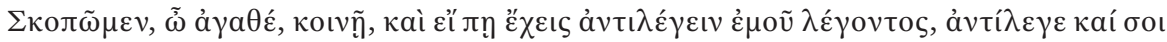

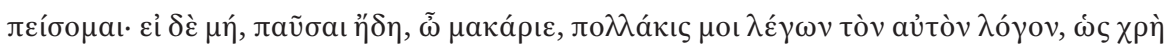

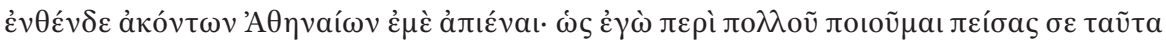

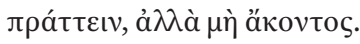

let us, my good friend, investigate in common, and if you can contradict anything I say, do so, and I will yield to your arguments; but if you cannot, my dear friend, stop at once saying the same thing to me over and over, that I ought to go away from here without the consent of the

\footnotetext{
${ }^{51}$ A clear case of wordplay occurs in this very passage ( $C r i .46$ b 5-7), where the passive form of the verb $\pi \varepsilon i \theta \omega$ is coupled with the noun $\lambda$ ó ${ }^{\prime}$ os to mean 'obey my speech' (Crito is the speaker) and 'be persuaded (dialectically) by an argument' (Socrates is the speaker).

52 Plat. Cri. 45 a 3, 46 a 8, 46 b 5, 47 c 1, 47 c 6, 47 d 10, 51 b 4, 51 c 1, 51 e 5, 51 e 6, 51 e 7, 51 e 8, 52 a 2, 53 a 7, $54 \mathrm{~b} 2$.

${ }^{53}$ He could have chosen other verbs such as akouō.

${ }^{54}$ In both cases Crito adds "and do not do any other thing", which emphasizes compulsion rather than mere persuasion; i.e., not "be persuaded by me" but "obey me".
} 
Athenians; for I am anxious to act in this matter with your approval, and not contrary to your wishes.

The dialectical nature of the passage is indicated by the verb a $v \tau \imath \lambda \varepsilon \dot{\varepsilon} \gamma \varepsilon \nu$. There is,

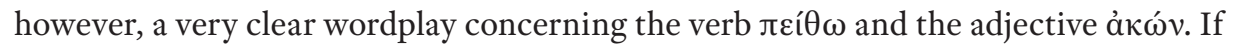
Crito engages in a dialectical conversation and really persuades him to run away, then

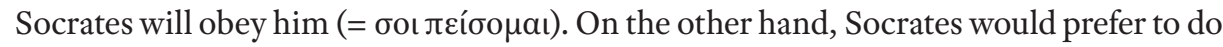
what he is already doing having persuaded Crito $\left(=\pi \varepsilon \varepsilon^{\sigma} \sigma a \varsigma \sigma \varepsilon\right)$. Crito tries to persuade

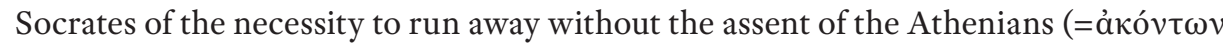

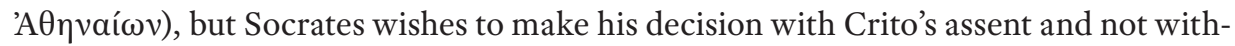

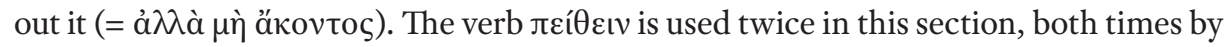
Socrates. The first time Socrates is talking about being persuaded by Crito if the latter

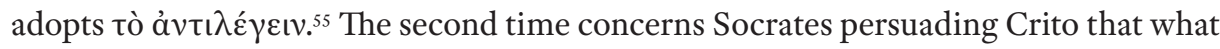
he is currently doing, remaining in jail, is correct. That is to say, on both occasions the context is dialectical. When referring to Crito's own attempts at persuasion, Socrates significantly does not use the verb, but instead chooses a circumlocution, "many times giving me the same speech."

The connection between speeches and persuasion is of course the main point of rhetoric, and in this dialogue one of Socrates' main criticisms against Democracy. ${ }^{56}$ Democracy's basic criterion for any decision is the opinion of the majority of citizens despite their having no real knowledge of the subject to be decided. Persuasion of the ignorant masses by an expert would have been ideal, but in Democracy, it is rhetoric which persuades, giving the speaker and his ignorant audience the false impression both that they know what they are deciding about, and that they decide freely. In the Gorgias this theme is well developed in Socrates' conversation with Polus, where Socrates even denies that rhetoric is an art ( $\mathrm{rrg} .462 \mathrm{~b} \mathrm{8-9)}$. It is a mere knack of persuasion, and it aims at gratification while being indifferent to truth. Even the expert has no need of his knowledge in order to make the crowd vote for his proposal, and can even deliver a proposal which he knows to be harmful for the state.

Rhetorical persuasion is not necessarily a bad thing. Ignorant persuasion (base rhetoric) needs to be distinguished from informed persuasion (philosophical rhetoric) used by the expert to persuade a crowd to accept his good proposal.

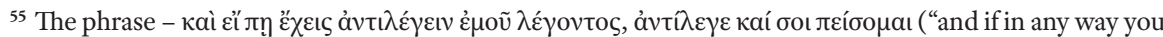
can contradict while I am speaking, contradict and I shall be persuaded by you") - may be understood in two ways. It may refer to content, the bringing of better arguments; or it may refer to form and method, the turning away from rhetorical speeches to dialectical give and take. I have adopted the second option. For other examples of phrases which may be read either as concerning content or method, see p. 155 above, and 161-162 below.

${ }^{56}$ This criticism is discernible in the Gorgias as well. Polus and Callicles are dramatized as pupils of Gorgias who have chosen to learn rhetoric in order to become politicians, and the connection with Democracy is brought out in the long conversation with Callicles (482c4-486d1).
} 


\section{The Many, Justice, and Rhetoric}

As I argued at the beginning of this paper, at 48 a 10 Socrates decides to change his strategy, and now - having failed in his previous discussions concerning the Many and Justice - he starts a new stage which culminates with the Laws' speech. This new strategy concentrates on Crito's use of persuasion, but incorporates the previous strategies as well, namely the Many and Justice. As the Crito is arranged around the theme of one who regards himself as a loyal and law-abiding citizen of a democratic regime but can still break the law for his own interests whenever it suits him, these three stages - the Many, Justice and persuasion - are but three ever widening dimensions exposing the basic corrupt infrastructure of democracy.

After Crito's first speech at 44 b 6-c 5 Socrates identifies Crito's dependence - or rather enslavement - to the opinion of the Many, ${ }^{57}$ according to which Crito is expected to smuggle Socrates out of jail..$^{58}$ Socrates' first attempt is to free Crito from his dependence on the Many by subtly identifying the epieikestato $i$ with the phronimoi, and the Many with the aphrones (Cri. $44 \mathrm{c} 6-\mathrm{d} 10$ ). Crito who surely considers himself to be phronimos might be expected to disconnect himself from the Many.

Crito, however, bursts in with another speech (Cri. 44 e 1-46 a 9), much longer than his first, in which he tries to find out what could prevent Socrates from escaping in order to refute it while also trying every possible argument to persuade Socrates to escape. It is during these attempts that the issue of Justice arises, and Socrates realizes that Crito's problem is much more complicated than it seemed at first. Crito is in thrall to the popular concept of justice, namely 'helping friends, and harming enemies'..$^{9}$

I have elsewhere analysed the section 46 b 1-48 a 4 which I take to be Socrates' attempt at making Crito understand that his concept of justice harms his own soul. ${ }^{60}$ The term 'soul' does not appear in this section (nor anywhere else in the Crito) but is only

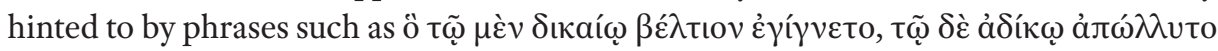
("that which becomes better by to dikaion and is ruined by to adikon") (Cri. 47 d 4-5)

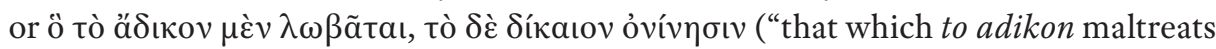
and to dikaion benefits") (Cri. $47 \mathrm{e} \mathrm{8).} \mathrm{The} \mathrm{formulation} \mathrm{"that} \mathrm{which} \mathrm{is} \mathrm{benefited} \mathrm{by} \mathrm{to}$ dikaion and is ruined by to adikon") (Cri. $47 \mathrm{~d} \mathrm{4-5)} \mathrm{seems} \mathrm{to} \mathrm{me} \mathrm{to} \mathrm{be} \mathrm{a} \mathrm{deliberate} \mathrm{ploy}$

\footnotetext{
${ }^{57}$ See Plat. Cri. 47 b 5-7: Oủkoũv $\varphi$

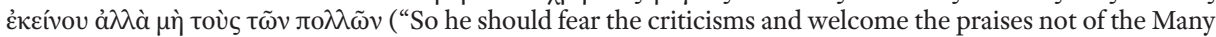
but of that one"). Socrates says this knowing full well that Crito is not only dependent on the Many, but afraid of them as well. On the tension between Crito's two motivations - the friendship with Socrates and his reputation among the Many - see n. 34 above.

${ }^{58}$ Here I shall pass over the self-contradiction the Many themselves fall into when expecting a good citizen such as Crito to break the laws they themselves have enacted.

${ }^{59}$ What we have called 'the measure for measure argument' does not appear here, but only later at 50c1-2 ('the state has done us injustice'). Only then can Socrates be sure that Crito subscribes to this argument, but he may suspect Crito of it at this stage, too.

${ }^{60}$ Liebersohn (2015).
} 
by Socrates to make Crito consider two options: soul and law $\{$ s $\}$. Since body appears as an example, it is only natural to think of its counterpart, soul; but the terms to dikaion and to adikon, as they appear and function in our dialogue, have the meaning of justice and injustice in terms of the law, ${ }^{61}$ and it might be assumed that laws are maintained by keeping them and are destroyed by breaking them. I maintain that Crito thinks of both possibilities and becomes confused. He cannot understand how his soul is connected with breaking the law - and Crito knows very well that committing to adikon (= breaking the law) is by definition nothing but destroying the laws. The final stage in the movement runs as follows (Cri. 47 e $7-48$ a 1):

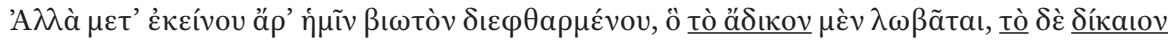

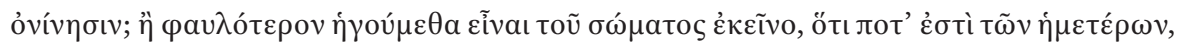

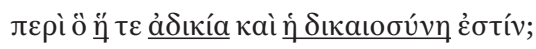

But is it worth living when that is ruined which is injured by the wrong and improved by the right? Or do we think that that part of us, whatever it is, which is concerned with adikia and dikaiosyne, is less important than the body?

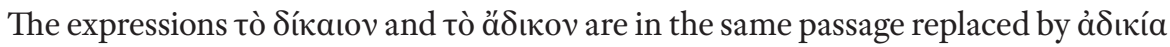
and $\delta$ ıкıо $v ́ v \eta .{ }^{62}$ This cannot be mere coincidence or sloppy writing. It is easy to see that

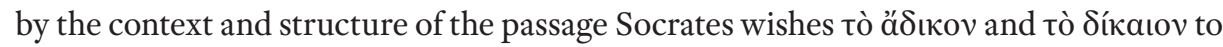

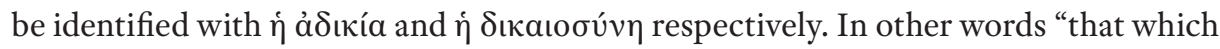

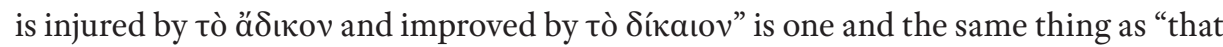

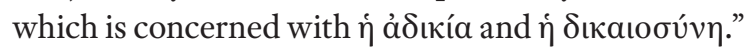

To Socrates' question at 47 e 7-48 a 1 above, Crito's answer is oủ $\delta a \mu \tilde{\omega} \varsigma$ ("by no means"). Yet, to what question does he reply? Socrates in fact ended with two questions.

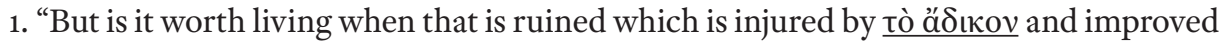
by tò díkatov?" 2. "Or do we think that part of us, whatever it is, which is concerned

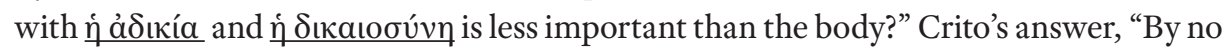
means", could refer to both questions. This is exactly the reason why Socrates further asks, "But more important?" This is to discover whether Crito's answer - oủ $\delta \alpha \mu \tilde{\omega} \varsigma$ - refers to the first question or to the second. When Crito answers "Much more", applicable only to the second question (that soul is superior to the body), Socrates understands that Crito has not made the connection between law-breaking and harming the soul, and moves on to his last attempt - the Laws' speech. Why Socrates is presented as deciding to turn

\footnotetext{
${ }^{61}$ Plato is very attentive to the different usages of the terms he puts in his characters' mouth. The terms to dikaion and to adikon (both in the singular and with the article) appear throughout the Crito in the context of abiding by or breaking the law. See Plat. Cri. 50 e 5, 50 e 8, 51 b 7, 51 c 1. See also Arist. Pol. 1253 a 37-39; EN 1134 a $12-16$. Justice in relation to the soul would normally be dikaiosyne (on which see Cri. 47 e 7-48 a 1 immediately below in the text).

${ }^{62}$ It is the only place in the dialogue where both pairs appear together.
} 
to the Laws' speech and why he prefers the Laws' speech rather than something else are two points the careful reader should consider.

The form and content of the Laws' speech should be noted. The content of the speech answers 'the measure for measure argument'. The Laws' main argument touches exactly on the lex talionis and actually dismisses it because of the asymetrical relations between Socrates and the Laws. The Laws are exerting their power, exactly as Crito did, and even using the same method, namely a rhetorical speech. According to the Laws the relation between them and Socrates is the same as between a master and his slave. Their power is so great that even if they really committed an act of injustice, Socrates is not in a position to pay them back. The preface to the speech (Cri. 50 a 6-50 c 3), needs to be distinguished from the argument of the speech itself. The preface is based on the fact that a city where laws are not obeyed is doomed, while the main argument is based on the mere fact that Socrates is a slave who has no right to counter injustice with injustice. It is in preparation for this that Socrates earlier elicits from Crito the admission that one should never retaliate (Cri. 49 c 10-11). ${ }^{63}$

The form in which these arguments appear is also important. It is a speech that touches upon the same issues Crito mentioned in his own speech but with an opposite evaluation, emphasizing in practice that every theme may be treated rhetorically in two opposing ways. Socrates would no doubt have wished Crito to understand, or at least feel, that using rhetorical speech is worthless as a tool for correct decision-making.

The form and content combined are designed to lead Crito to yet another conclusion, that the use of rhetorical speech is nothing but violent compulsion. Crito's sense of justice as 'helping friends and harming enemies' is so deep-rooted that Socrates never tries to change this meaning but attempts to reveal this ancient code to be a double-edged sword. You may use rhetorical speeches in your attempt to help friends and harm enemies, but so may your enemy. The Laws' speech, then, is intended to make Crito aware that speeches are worthless, violent, and double-edged; Crito would have done well to conclude that he should refrain from making speeches. This brings us back to the passage with which this paper began.

\section{The End of the Dialogue}

We noted at the beginning of the paper that Socrates in the last section of the Crito, now speaking in his own person after delivering the Laws' speech, seems to be indecisive at the very least. On the one hand he is unwilling to hear Crito, but in the same breath he emphasizes that if Crito thinks he has something new to say he may say it (Cri. $54 \mathrm{~d} \mathrm{6-8) \text {: }}$

\footnotetext{
${ }^{63}$ The whole passage at $49 \mathrm{c} 4-49 \mathrm{~d} 11$, manifestly a preparatory passage to the Laws' speech, has nevertheless puzzled not a few scholars, such as Gregory Vlastos (1991: 179-199) who understood Socrates to have reached new heights in ethics with this novel position. For a criticism of this view see Liebersohn (2011).
} 


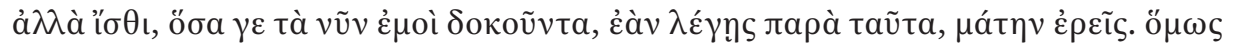

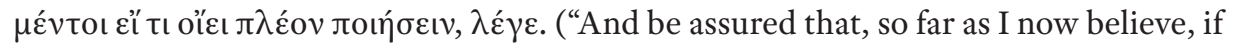
you argue against these words you will speak in vain. Nevertheless, if you think you can accomplish anything, speak").

Interestingly, Socrates does not wait to hear what Crito has to say in response to the Laws' speech but declares his unwillingness to hear any response. Socrates evidently does not want to hear another speech. If so, why would Socrates go on to offer Crito the chance to speak? By now it should be clear that Socrates is appealing to Crito to change his method.

Earlier scholars have assumed that it is the content at issue, rather than the form. The trend has been to regard Socrates as accepting the arguments presented by the Laws (e.g., Kraut 1984). In a famous paper, already mentioned, Harte (2005: 230) bucks the trend by denying that Socrates accepts the arguments: "when someone is 'Corybantically' affected by an argument, the argument is one they would not, or should not, endorse.” It is my contention that the focus should be turned away from the Laws' arguments to the fact that they use rhetorical speech just as Crito has done. It is the rhetorical tool of compulsion that Socrates does not accept.

Socrates, then, is not being indecisive: he does not want a third speech, but he does not want the conversation to come to an end either, as the verb $\lambda \dot{\varepsilon} \gamma \varepsilon$ (speak) indicates. Socrates has in mind the other technē of logos, dialectic, whose end is rightness or correctness (orthotess).

Socrates chooses to end his conversation with Crito by hinting at the need for dialectic to replace rhetoric as the means to arrive at correct decisions, based on free will rather than compulsion. On another level, Plato the author guides the reader through three corrupt levels underlying Democracy: the Many, democratic justice, and rhetoric. The Many dominate the polis and are its most physical expression. The citizen is to obey the laws enacted by the Many, but is also expected by the same Many to break these laws when they clash with their concept of justice which is nothing but the popular moral code of helping friends and harming enemies; public opinion is such that it is in the interest of a citizen to follow the code rather than the laws in those cases where they clash. The violent means with which to compel enforcement of the laws and of the moral code alike are - for typical citizens most of the time - rhetorical speeches.

Crito as the typical Athenian citizen surely misunderstands Socrates' command to speak (i.e., dialectically) as a request for another speech that Socrates has already stated

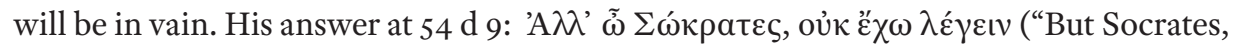
I cannot speak" or "I have nothing to say") indicates that he is still thinking in rhetorical terms: a dialectician need only have asked questions. This should come as no surprise. Plato wrote the dialogue not for the benefit of the characters in his dialogue but for the reader. 


\section{BIBLIOGRAPHY}

AdAM, J., 1888, Plato: Crito, Cambridge.

Allen, D.S., 2000, The World of Prometheus. The Politics of Punishing in Democratic Athens, Princeton.

Brickhouse, T., 1983, “Socrates and Legal Obligation”, New Scholasticism 57, pp. 277-282.

Congleton, A., 1974, “Two Kinds of Lawlessness: Plato's Crito”, Political Theory 2, pp. 432-46.

DANzIG, G., 2010, Apologizing for Socrates: how Plato and Xenophon created our Socrates, Lexington.

DASTI, M.R., 2007, “The Crito's Integrity”, Apeiron 13, pp. 519-535.

Dover, K.J., 1974, Greek Popular Morality in the Time of Plato and Aristotle, Oxford.

Dyer, L. (ed.), 1885, Plato: Apology of Socrates and Crito, T.D. Seymour (rev.), Waltham, Mass.

GARver, E., 2012, "Plato's Crito on the nature of Persuasion and Obedience”, Polis 29, pp. 1-20.

HARTE, V., 2005, “Conflicting Values in Plato's Crito”, in: R. Kamtekar (ed.), Plato's Euthyphro, Apology, and Crito, Lanham, pp. 229-259 (Originally published in Archiv für Geschichte der Philosophie 81 (1999), pp. 117-47).

KaHN, C., 1989, "Problems in the Argument of Plato's Crito", Apeiron 22, pp. 29-43.

KraUt, R., 1984, Socrates and the State, Princeton.

LiEBERSOHN, Y.Z., 2011, "Rejecting Socrates' Rejection of Retaliation”, Maynooth Philosophical Papers (MPP) 6, pp. 45-56.

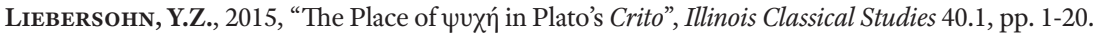

Long, C., 2014, Socratic and Platonic Political Philosophy, Cambridge.

Miller, M., 1996, “The Arguments I seem to Hear: Argument and Irony in the Crito”, Phronesis 41, pp. $121-137$.

Moore, C., 2011, "Socratic persuasion in the Crito", British Journal for the History of Philosophy 19, pp. 1021-1046;

Stokes, M., 2005, Dialectic in Action: An Examination of Plato's Crito, Swansea.

ToDD, S.C., 1993, The Shape of Athenian Law, Oxford.

VLAstos, G., 1991, “Socrates' rejection of Retaliation”, in: G. Vlastos, Socrates, Ironist and Moral Philosopher, Cambridge, pp. 179-199.

WeIss, R., 1998, Socrates Dissatisfied: An Analysis of Plato's Crito, Oxford.

Woozley, A.D., 1979, Law and Obedience: The Arguments of Plato's Crito, London.

YOSEF Z. LIEBERSOHN

/Bar-Ilan University /

\section{Persuasion, Justice and Democracy in Plato's Crito}

Speeches and persuasion dominate Plato's Crito. This paper, paying particular attention to the final passage in the dialogue, shows that the focus on speeches, persuasion and allusions to many other elements of rhetoric is an integral part of Plato's severe criticism of democracy, one of the main points of the Crito. Speeches allow members of a democracy - represented in our dialogue by Crito - firstly to break the law for self-interested reasons while considering themselves still to be lawabiding citizens, and secondly to feel that they are in a tolerant society preferring logos/persuasive speech above bia/compulsion. Socrates 
counters Crito's speeches with speeches of his own, not only to defeat him at his own game, but also to make him aware how dangerous the game is. Real knowledge is preferable to speeches, but a democracy without speeches and rhetoric is doomed. 